\title{
Developing Fishing Tourism Destination Based on "Anak Nagari” Concept in Padang City
}

\author{
${ }^{1}$ HARYANI, ${ }^{2}$ NURUL HUDA \\ ${ }^{1}$ Faculty of Civil Engineering and Planning, Bung Hatta University, Jl. Sumatera Ulakkarang Padang, \\ 2 Faculty of Economics, Bung Hatta University, Jl. Sumatera Ulakkarang Padang \\ email: 1irharyanimtp@yahoo.co.id,2nurulhuda114@yahoo.com
}

\begin{abstract}
Spatial potentials and problems in coastal areas are complex, ranging from potential and economic problems, geographical vulnerability, social vulnerability to human resources and resources being managed less than optimal. This study aims to develop a fishing village based on the concept of "Anak Nagari" as a new tourist destination in the city of Padang with community empowerment. This research uses qualitative descriptive research method with scoring/weighting analysis and SWOT analysis (Strength, Weakness, Opportunity and Threat). The result obtained is the high potential of fishing village of Pasie Nan Tigo with its many attractions of fishing communities' activities and original environment that can be developed as tourist destinations. Having high access of location close to the center of Padang City and Minangkabau International Airport as its strength and opportunity, Pasie Nan Tigo Fisherman Village is a fishing village which still holds a strong social and cultural life of "Anak Nagari". It exists as cultural treasure in the middle of modern life, but at the same time can also be a threat for the development of fishing village.
\end{abstract}

Keywords: Development, fishing village, "Anak Nagari"

\section{Introduction}

Indonesia is the largest archipelagic country in the world with $\pm 17,508$ islands and $95,181 \mathrm{~km}$ of coastline. Total area of Indonesia is approximately 9 million $\mathrm{km} 2$ consisting of 2 million $\mathrm{km} 2$ of land and 7 million $\mathrm{km} 2$ of ocean with various potentials. Unfortunately, about $80 \%$ of coastal population, especially in developing countries such as Indonesia, are living in poor conditions with degraded coastal environment (Muhammad Syafii, 2015). Developing the potential of coastal resources to become a capital can be done by, one of them is, developing coastal tourism. West Sumatra Province has a coastline of approximately $375 \mathrm{~km}$. The capital of attraction must be utilized optimally through the implementation of tourism in general which aims to increase regional income and improve people's welfare, especially coastal communities. The problem often occur in the management of tourism in addition to decreasing the quality of the environment and the presence of insufficient facilities and infrastructure is the lack of integration between the surrounding communities with the tourism area itself. This is because the benefits resulting from the presence of tourist areas have not been fully felt by the surrounding community and cause a lack of sense of ownership for the tourist area. In terms of the existence of the community, its cultural potentials such as traditional ceremonies and other local wisdom can be developed to support the tourism.

The city of Padang as the capital of West Sumatra Province is geographically a coastal city bordering the Indian Ocean. It has the potential of coastal tourism, maritime and cultural tourism as well as the potential of the fishery sector. One of the mainstay attractions in the city of Padang is a beach tour. The result of research by Haryani (2016) states that one of coastal tourism object in Padang City is coastal area of Pasie Nan Tigo (PNT) which is one of big fishing villages in Padang City and has coastal tourism potency. In addition to the tourism potential of fisherman village PNT, it has a variety of threats of abrasion and extreme haze that makes the coastal

Received: September 14, 2017, Revision: January 17, 2018, Accepted: June 04, 2018

Print ISSN: 0215-8175; Online ISSN: 2303-2499. DOI: http://dx.doi.org/10.29313/mimbar.v34i1.2990.51-60

Accredited B based on the decree No.040/P/2014, valid on February, 18, 2014 until February, 18, 2019. Indexed by DOAJ, Sinta, IPI 
region increasingly apprehensive (Haryani, 2012 \& amp; 2014). Furthermore, another problem occurs in the area of Pasie Nan Tigo of Padang City is the absence of marine resources and coastal tourism utilization as optimal attractions. The Tourism Development Master Plan (RIPP) Padang 2008-2017 has established Pasie Nan Tigo as one of the coastal attractions, but the fact that there are no tourist attraction worthy of sale and the absence of representative facilities and facilities like a tourist attraction, in terms of environmental potential and culture is unfortunate.

Besides having the potential of coastal and marine tourism, Pasie Nan Tigo has also potential of fishing village tourist destination as an alternative of new tourist village destination in the city of Padang. Furthermore, it is expected that Pasie Nan Tigo fishermen can be developed as one of the tourist destinations which involves community participation so that one by one the problems that happened in the tourism field of Padang City can be resolved. By involving community participation in the management of fisherman's fishing village from planning, implementation to monitoring, it is expected to be an alternative source of livelihood for coastal communities, especially fishermen (Haryani, 2012 and 2014). Fisherman of Pasie Nan Tigo has a potential of fishing village worthy to be developed as well as one of the new tourist destinations in the city of Padang. The problem is how to develop this fisherman's area to become a tourist attraction of fishing village by involving community participation as a new tourist destination in the city of Padang. Land space, coastal and sea should be utilized optimally for the benefit of people. Spatial and tourism are elements that closely related to each other. Law no. 26 of 2007 on Spatial Planning mentioned space is a container that includes land space, sea space and airspace including space within the earth as a unity of territory where humans and other living creature conduct activities and maintain its survival. The coastal area is a unique area because it is a land and sea meeting as part of the space that needs to be managed properly. In Law No.27 of 2007 on the Management of Coastal Areas and Small Islands, coastal areas are transitional areas between terrestrial and marine ecosystems that are affected by changes on land and sea. With its unique characteristics and geographically, the coastal area has become a marine and coastal tourism destination.
Coastal management is not only from the marine and fisheries sector but also from the tourism sector. In the Law No.10 of 2009 on Tourism mentioned that the determination of a strategic area of tourism is done by showing the natural tourism and cultural resource potential of tou rism attraction. Municipal/regional governm ents are authorized to conduct tourism research within the scope of Kota (city)/Kabupaten (regency) and organize guidance of the conscious tourism community. Tourism village is one form of application of community-based and sustainable tourism development. The development of tourist villages is expected to be equitable in accordance with the concept of sustainable tourism development. In addition, the existence of tourist villages make tourism products of rural culture more valuable so that the development of cultural tourism village can be done without harming the environment (Muhammad Syafii, 2015). In line with its dynamics, the movement of tourism development penetrated in various terminologies such as sustainable tourism development, rural tourism, and ecotourism. It takes tourism development approach that seeks to ensure that tourism can be implemented in non-urban tourist destinations. One approach to developing alternative tourism is tourism villages for sustainable rural development in tourism (Faris Zakaria, 2014) For the development of a tourist area, not solely rely on the mere attractiveness. Many factors that influence them are the availability of transportation, services and accommodation such as hotels, food and beverage and tourism facilities and infrastructures.

Oka A.Yoeti (2008) said developing tourist destination area should consider things as follows; 1 ) the existence of attraction, which is attractive and reliable tourism object. Attractions must be easily accessible, unique and high value 2) Supporting facilities such as hotel/inn, transportation, souvenir shop, good infrastructure etc. 3) Accessibilities, object/tourist attractions that are easy to be reached, with the availability of and etc. Many related sectors are involved in tourism development. According to Oka A. Yoeti (2008), it is necessary to know the factors: tourists (domestic and foreign), transportation (land, sea, air, domestic), tourism objects and attractions (seen, purchased and done) and information/promotion (advertisements and brochures). Local people play an important role in the development of tourist villages 
because the resources and uniqueness of traditions and culture that inherent in the community become the main driving element of tourism village activities (Buku Pedoman Kelompok Sadar Wisata oleh Kementerian Pariwisata dan Ekonomi Kreatif, 2012).. On the other hand, local communities that grow and co-exist with a tourist attraction become part of an interconnected ecological system. The success of developing a tourist village depends on the level of acceptance and support from local communities (PP No.69/1996 \& Haryani, 2016). Communities in the development area should be encouraged to identify their own objectives and guide tourism development to improve the needs of local communities. Thus, tourism development planning should accommodate the desire and ability of local communities to participate and obtain maximum benefit value from tourism development (Chafid Fandeli, 2013).

Activities and behavior of fishing communities can be identified in socio-cultural and economic behavior. The socio-cultural behavior is shown through the presence of several characters, namely: a) Interaction of high clusters due to addition of life span of the biduk/boat which is long enough (between 8 hours a day, even up to 3-4 days) and the challenge of life that is very big that resulted in high attachment and dependence on community, b) Conventions often occur in the community of fishermen, ranging from the level of agreement on the sale and purchase of fish, boat users, linkages with the level of community leadership related to the agreement of the catchment areas. Thus the groupings occur in the environment of fishermen will be very strong since they are based on the existence of these agreements. c) The formation of kinship characterizes the settlement arrangement of fishing communities. The kinship formed based on the regional bonds is the basis of the settler's origin, the livelihood link as specification of a fisherman, as a craftsman of small fishing industry, the bond of diversity, and the bond of psychological condition. The kinship ties lead to a tendency for clustering between settlement units and the need of space for activity. On the economic aspect, the behaviors of fishing community are; a) Limited knowledge, skills and characteristic traits attached to fishermen and difficulty to enter a formal economic pattern. This is for the increasingly isolated fishing grounds, b) The chain of economic activities of the community, both in form of basic livelihoods and complementary livelihoods through small home businesses and traditional industries that create the need for transitional spaces against spatial pattern of the area. The implications of such social and economic behavior will lead to the formation of settlement structures.

\section{Research Methods}

This research is descriptive qualitative with research approach of (1) functional approach; (2) socio-economic approach and; (3) behavioral and cultural approaches. The method of data collection used in this research is the community participation method (Rapid Rural Appraisal/RRA and Participatory Rural Appraisal/PRA) while the analytical method is scoring analysis/weighting and SWOT analysis.

\section{Potential Tourist Attraction}

Village fisherman of Pasie Nan Tigo (PNT) is one of the fishermen villages in Padang city that has the potential to be developed as a fishing village. It is hoped that the role of community-based tourism village in PNT that formed a linkage between local economy and preservation of local culture, would be able to walk in harmony and sustainability. The conditions of a fishing village PNT can be seen from the attraction factors, human resources and organizations/ institutions that will be described as follows. The unique tourist attraction is one of the basic capitals to develop tourism. In addition, it is also a core element of tourism products. Without a typical tourist attraction, satisfaction in tourism will not be achieved, although facilities and services, conferences, places of worship, and various travel agencies are available. Kelurahan (administrative of urban village) PNT is one of the urban villages in Padang that has the potential of nature and culture to be developed into a new tourist destination, that is a fishing village. This is supported by the natural physical and sociocultural conditions of the region. The following is the attractiveness of the fishing village that can be developed in PNT.

The facilities and infrastructure in tourism object location are generally consist of toilets, gazebo, playground, parking lot, souvenir shop, electricity, clean water, drainage, telephone, and trash bin. The criteria of assessment of variety and quality of facilities and infrastructure of tourism support 
Table 1

Cultural and Environmental Potential Fisherman Tourism Village of Pasie Nan Tigo

\begin{tabular}{|c|c|c|c|}
\hline Potency & $\begin{array}{l}\text { Location } \\
\text { /RW }\end{array}$ & Attractiveness & Tourist Attractions \\
\hline \multirow[t]{6}{*}{ Culture } & $\begin{array}{l}\text { RW III, IV, } \\
\text { VI, VIII, } \\
\text { IX, X, XII }\end{array}$ & Cultural Attractions & $\begin{array}{l}\text { a) "Tolak Bala" (danger deterrent); is a } \\
\text { customary event containing safety } \\
\text { prayers to keep away the disasters } \\
\text { and distress and to improve the catch } \\
\text { result of fishermen. }\end{array}$ \\
\hline & & & $\begin{array}{l}\text { b) "Mandarahi Biduk"/"Malimau Kapa" is } \\
\text { a ritual performed when new boats/ } \\
\text { vessels/ships are purchased so that } \\
\text { the ship brings blessings, able to get } \\
\text { many results, safe to be used and } \\
\text { protected by the Almighty God. It is a } \\
\text { ceremony to ask permission to Allah } \\
\text { SWT to manage the contents of the } \\
\text { oceans and toss out bad luck. }\end{array}$ \\
\hline & & $\begin{array}{l}\text { Customary System of West } \\
\text { Sumatera in general and } \\
\text { Minangkabau in particular } \\
\text { (including Pasie Nan Tigo } \\
\text { Urban Padang Village), is } \\
\text { known as a region that } \\
\text { upholds custom and religious } \\
\text { value It can be seen from } \\
\text { the philosophy of life that } \\
\text { has become the ideals and } \\
\text { guidelines in the life of the } \\
\text { community. The value of the } \\
\text { philosophy of life is "Adat } \\
\text { Basandi Syarak, Syarak } \\
\text { Basandi Kitabullah", which } \\
\text { means is custom based on the } \\
\text { Shari'a, the Shari'ah based on } \\
\text { the holy book of the Qur'an }\end{array}$ & $\begin{array}{l}\text { c) Customary System of Fisherman } \\
\text { Village PNT. The positive values } \\
\text { of socio-cultural aspect of Padang } \\
\text { City and Minangkabau society in } \\
\text { general is the value of togetherness, } \\
\text { democracy and mutual cooperation. } \\
\text { Barek samo dipikua, ringan samo } \\
\text { dijinjiang, saciok bak ayam, } \\
\text { sadantiang bak basi, duduak samo } \\
\text { randah, tagak samo tinggi, duduak } \\
\text { saurang basampik-sampik, duduak } \\
\text { basamo balapang-lapang which } \\
\text { means whether heavy or lightweight } \\
\text { borne together, having the same } \\
\text { and agreed opinions, being together } \\
\text { in the same level, and live. The } \\
\text { above values are expected to be well } \\
\text { actualized in the "nagari" government } \\
\text { system currently being developed } \\
\text { throughout the province of West } \\
\text { Sumatra, and Padang City as the } \\
\text { provincial capital }\end{array}$ \\
\hline & & $\begin{array}{l}\text { Traditional Fisherman } \\
\text { Attraction Traditional fishing } \\
\text { activities are very interesting, } \\
\text { such as "mahelo pukek" which } \\
\text { is pulling out net to the sea to } \\
\text { get fishes and done together; } \\
\text { cleaning, boiling and drying } \\
\text { fish in traditionally. }\end{array}$ & $\begin{array}{l}\text { The main activity of fishermen } \\
\text { a) "Bagan" fishermen (ship, a few days) } \\
\text { b) "Payang" fishermen (motorboat, } 1 \\
\text { day) } \\
\text { c) "Pukek" fishermen (canoe, without } \\
\text { machine, several hours) } \\
\text { d) "Pancing" fishermen (at certain time) }\end{array}$ \\
\hline & $\begin{array}{l}\text { 4/VIII, 4/ } \\
\text { IX, 3/IX, } \\
2 / \mathrm{VII}, 4 / \mathrm{X} \\
2 / \mathrm{XIV}\end{array}$ & Fisherman Attraction & $\begin{array}{l}\text { Complementary activities of fishermen } \\
\text { a) Repairing and making boats/ } \\
\text { ships/"biduk" } \\
\text { b) Repair and make nets } \\
\text { c) Painting and designing the main boat } \\
\text { d) Make the rudder "biduk" ("daun } \\
\text { biduk") } \\
\text { e) "Memanjek Karambia jo baruak" } \\
\text { (Climbing the coconut trees) }\end{array}$ \\
\hline & $\begin{array}{l}4 / X I V, 2 / \\
\text { IV, 4/IX, } \\
2 / \mathrm{VI}\end{array}$ & $\begin{array}{l}\text { Family Activities of Fishermen } \\
\text { (Wife and Child) }\end{array}$ & $\begin{array}{l}\text { Culinary activity } \\
\text { a) "lauak karang/pukek" }\end{array}$ \\
\hline
\end{tabular}




\begin{tabular}{|c|c|c|c|}
\hline & $\begin{array}{l}\text { VIII, X, } \\
\text { VI, IX, III, } \\
\text { XIV }\end{array}$ & & $\begin{array}{l}\text { b) Palai Bada (Pepes ikan teri) dan Palai } \\
\text { Pucuak Parancih (Palai pucuk/daun } \\
\text { ubi) }\end{array}$ \\
\hline & III, X, VI & & c) Rakik Maco (Rempeyek ikan "maco") \\
\hline & III, VIII & $\begin{array}{l}\text { Family Activities of Fishermen } \\
\text { (Wife and Child) }\end{array}$ & $\begin{array}{l}\text { Traditional Fish Processing } \\
\text { Traditional fish processing }\end{array}$ \\
\hline & & Children's Activities fishing & Traditional children's games \\
\hline \multirow[t]{3}{*}{ Natural } & $\begin{array}{l}\text { Muara } \\
\text { Penyalinan } \\
\text { and Muaro } \\
\text { Baru }\end{array}$ & $\begin{array}{l}\text { Estuary (sea and beach } \\
\text { encounters), natural beauty, } \\
\text { siltation at the estuary } \\
\text { becomes a new beach }\end{array}$ & $\begin{array}{l}\text { Fishing, enjoying nature muaro scenery } \\
\text { and beaches, beach sports (volley, kite } \\
\text { playing), swimming, surving, canoing, } \\
\text { boots }\end{array}$ \\
\hline & Beach & $\begin{array}{l}\text { Natural beauty, sloping } \\
\text { beach }(0-2 \%), \text { brown sand, } \\
\text { wide enough ( } 2 \text { s / d } 21 \mathrm{~m}) \text {, } \\
\text { marine sediment, there is } \\
\text { greening (sea cypress } 15.59) \text {, } \\
\text { vegetation (coconut area of } \\
7.04 \text { ha, mangrove/sonneratia } \\
\text { alba area of } 6.03 \text { ha, nipah/ } \\
\text { nypa fructicans area of } 0.15 \\
\text { ha) }\end{array}$ & $\begin{array}{l}\text { Fishing, boating, enjoying beach, beach } \\
\text { scenery (volley, kite play), swimming, } \\
\text { bike trails, residents' trekking, hunting, } \\
\text { horse riding, camping. }\end{array}$ \\
\hline & $\begin{array}{l}\text { River of } \\
\text { "Muaro Pe- } \\
\text { nyalinan" } \\
\text { \& "River } \\
\text { of Batang } \\
\text { Kandis" at } \\
\text { RW XIV \& } \\
\text { VII }\end{array}$ & $\begin{array}{l}\text { The beauty of nature, there are } \\
\text { mangrove and nipah forest, } \\
\text { there are many different types } \\
\text { of estuary fish, landing places } \\
\text { fishing boats, rivers are deep } \\
\text { enough }\end{array}$ & $\begin{array}{l}\text { Fishing, enjoying the natural scenery, } \\
\text { boating (canoing), trekking the palm and } \\
\text { mangrove forests, jetski }\end{array}$ \\
\hline
\end{tabular}

with variable level of availability and quality of facilities and infrastructure of tourism in fishing village PNT can be seen in Table 2.

Table 2

\section{Type of Tourist Attraction of Pasie Nan} Tigo Village Fisherman

\begin{tabular}{|c|l|}
\hline No & \multicolumn{1}{|c|}{ Tourist Attraction type } \\
\hline \hline 1 & Culinary tour "lauk karang", "lauak pukek" \\
\hline 2 & $\begin{array}{l}\text { Traditional market snack tour; "palai } \\
\text { bada", "palai pucuk parancih", "rakik } \\
\text { maco", "lamang tapai", }\end{array}$ \\
\hline 3 & $\begin{array}{l}\text { Tourist attractions of fishermen: "mahelo } \\
\text { pukek", "mamukek", "mamancing", } \\
\text { "manjalo", "kalauik", "mambuek anak } \\
\text { biduak", "mambuek bagan/biduak", } \\
\text { "mampaeloki bagan/biduak, pukek", } \\
\text { mamiliah lauak" }\end{array}$ \\
\hline 4 & $\begin{array}{l}\text { Tour attractions of processing traditional } \\
\text { seafood products; }\end{array}$ \\
\hline 5 & $\begin{array}{l}\text { Search the beach: jo sepeda, "babendi", } \\
\text { "bakudo", fishermen's home search }\end{array}$ \\
\hline 6 & $\begin{array}{l}\text { Play the kite danguang-danguang", } \\
\text { "malapeh tukiak", "mamanjek karambia } \\
\text { jo baruak", "mancolok jariang jo kuliak } \\
\text { muba", children's traditional games. }\end{array}$ \\
\hline 7 & $\begin{array}{l}\text { Cultural attractions: "tolak bala", "mancat } \\
\text { biduak" }\end{array}$ \\
\hline
\end{tabular}

The assessment analysis of variety and level of quality of infrastructure facilities in tourist village of PNT fishermen varied from less to well assessment. Sightseeing at fishing village PNT can be done by land transportation, sea and air. Its proximity to Minangkabau International Airport (BIM) and downtown Padang and bypassing the Provincial road links lead to a range of services from and to the fishing village of PNT, not only at local scale (Padang City), but regional, national and even foreign countries.

\section{The Development of PNT Fisherman Tourism Village}

The following is an analysis of development of Pasie Nan Tigo fishing village indicators. The results of analysis of development indicators of Pasie Nan Tigo fishing showed that it had a high potential value to be developed as a tourist village, although there are still some indicators that must be addressed and equipped so that the potential has a high selling value as a new tourist destination. 
Table 3

Variety and Quality of Supporting Infrastructure Facilities in Pasie Nan Tigo

\begin{tabular}{|c|c|c|c|}
\hline Type & Information & Type & Condition \\
\hline \multirow[t]{4}{*}{ Accessibility } & $\begin{array}{l}\text { Mileage from downtown Padang } \\
\text { is } 15 \mathrm{~km} \text { away }\end{array}$ & Arterial road, asphalt & Good \\
\hline & $\begin{array}{l}\text { Mileage from BIM (Minangkabau } \\
\text { International Airport is } 15 \mathrm{~km}\end{array}$ & Arterial road, asphalt & Good \\
\hline & $\begin{array}{l}\text { Road environment in the fishing } \\
\text { village }\end{array}$ & $\begin{array}{l}\text { A small bit of asphalt and cast cement, } \\
\text { the rest of the dirt / sand roads are } \\
\text { mainly roads along the coast }\end{array}$ & Enough \\
\hline & Types of transportation & $\begin{array}{l}\text { Air, land and sea are available. Public } \\
\text { transport, personal, oplet, motorcycle } \\
\text { taxi, travel }\end{array}$ & Good \\
\hline \multirow[t]{10}{*}{ Amenities } & Public and social facilities & $\begin{array}{l}\text { Electricity network, clean water, } \\
\text { telecommunication, banks }\end{array}$ & Good \\
\hline & Restaurants & $\begin{array}{l}\text { Restaurant "Coral Reef"/ typical food } \\
\text { stalls in PNT are } 16 \text { units }\end{array}$ & Enough \\
\hline & Stalls sell typical PNT food & $\begin{array}{l}\text { Shop of "palai bada", "rakik maco" } \\
\text { are14 units }\end{array}$ & Enough \\
\hline & Lodging & $\begin{array}{l}\text { Jasmine class, home of typical } \\
\text { fisherman PNT as homestay }\end{array}$ & Less \\
\hline & Trading facilities & $\begin{array}{l}\text { Traditional market "Pasa Pagi Kali } \\
\text { Mati" }\end{array}$ & Enough \\
\hline & $\begin{array}{l}\text { Kampung Wisata (tourism } \\
\text { villages) facilities }\end{array}$ & $\begin{array}{l}\text { Road along the beach, "medan nan } \\
\text { bapaneh," parking lot }\end{array}$ & Enough \\
\hline & \begin{tabular}{|l|l|} 
Fishermen facilities \\
\end{tabular} & $\begin{array}{l}\text { Traditional boat belay place in Muaro } \\
\text { Penjalinan and along the coast of PNT }\end{array}$ & Less \\
\hline & & TPI joined "Pasa Pagi" & Less \\
\hline & & Depo oil /SPDN & Less \\
\hline & & $\begin{array}{l}\text { Traditional fish processing (cleaning, } \\
\text { boiling, fogging, soaking, drying) }\end{array}$ & Less \\
\hline
\end{tabular}

\section{SWOT Analysis Development of Fisherman's Village Tourism}

SWOT analysis is used to develop fisherman's tourism as a strategy based on the strengths, weaknesses, opportunities, and threats that exist in the fishing village of PNT.

\section{Conceptual and Management}

Community development is a combination of natural tourism (coastal and marine) and culture of fisherman community of "PNT Nagari" (ecotourism) which is expected to give multiplier effect to the growth of various aspects of fishermen's life, especially economic improvement through additional revenue from tourism activities. The development of fisherman's village tourism of "Anak Nagari Pasie Nan Tigo", directed to cooperation with big companies around the area as a form of CSR (Corporate Social Responsibility)/Community Development program. Through the development of new tourist destinations of PNT fisherman's tourism village in the city of Padang, it is expected to provide wealth from tourist visits and will increasing in the future.

The development of PNT fisherman village tourism is expected to become a snowball that will grow larger when it rolled out, in this case positively impact to other sector's growth, such as improvement and development of infrastructure, especially roads, drainage and water supply in fishermen's neighborhood, tourism facilities and infrastructures the fishing village of PNT.

To realize the fishing village of PNT, the concept of management development is as follows: (1) The PNT fisherman's village tourism is targeted as a tourism activity managed by the community of Anak Nagari (self-help community); (2) In the early stages, it takes a power or drive with no orientation solely to the material; (3) PNT fisherman tourism village developed by the NGO "Anak Nagari Pasie Nan Tigo." The network development/marketing activities 
Table 4

Analysis of Development Indicators of PNT Fisherman Tourism Village

\begin{tabular}{|c|c|c|c|c|c|}
\hline No & Aspect & $\begin{array}{c}\text { Indicators of sustainable tourism } \\
\text { development }\end{array}$ & Weight & Score & Value \\
\hline \multirow[t]{3}{*}{1} & $\begin{array}{l}\text { Physical and } \\
\text { Environ } \\
\text { ment }\end{array}$ & $\begin{array}{l}\text { Tourist attractions } \\
\text { - Has a culture value of original/traditional } \\
\text { - Tishing village } \\
\text { - The existence of a unique fishing community } \\
\text { village } \\
\text { - Have a traditional system of "Minangkabau" } \\
\text { - Coastal environmental resources that are still } \\
\text { original }\end{array}$ & 25 & 3 & 75 \\
\hline & & $\begin{array}{l}\text { Accommodation } \\
\text { - The home of a community of fishermen which } \\
\text { are ready to be used as homestay } \\
\text { - Available electricity, water supply, } \\
\text { telecommunication }\end{array}$ & 15 & 2 & 30 \\
\hline & & $\begin{array}{l}\text { Transportation } \\
\text { - Easy access by arterial road } \\
\text { - Close to the city center }(15 \mathrm{~km}) \\
\text { - Transportation modes are available both at } \\
\text { local and in the fishing village } \\
\text { - Types of asphalt road and environmental road } \\
\text { type of cast /cement and soil }\end{array}$ & 10 & 3 & 30 \\
\hline 2 & Social & $\begin{array}{l}\text { Institutional } \\
\text { - RT, RW, BKM, Fishermen Cooperative, } \\
\text { BPM,Pokmas PNT } \\
\text { - Coordination with City Government of } \\
\text { Padang through related SKPD; Department } \\
\text { of Tourism and Culture, Bappeda, DKP, BPBD } \\
\text { - Private through CSR programs }\end{array}$ & 20 & 2 & 40 \\
\hline \multirow[t]{3}{*}{3} & Economi & $\begin{array}{l}\text { Accommodation } \\
\text { - Available transportation of land, sea and air } \\
\text { transportation }\end{array}$ & 15 & 3 & 45 \\
\hline & & $\begin{array}{l}\text { Trade and Service } \\
\text { - Locally and traditionally } \\
\text { - Limited to primary sector }\end{array}$ & 15 & 2 & 30 \\
\hline & Amount & & 100 & & 250 \\
\hline
\end{tabular}

and tourism package management are in cooperation with higher education, travel bureau and hotel; (4) Socialization and guidance is done from Lurah (head of the village), ninik mamak, clerical, scholars, NGO, Pokdarwis Nagari, fishermen community and PNT community done in stages and simultaneously through the effort to attract tourist visit to the fishing village.

\section{Conclusion}

The concept of developing PNT fishing village is to involve fishermen community/ Pokdarwis of "PNT Nagari" in the development of fisherman's fishing village starting from the planning stage, implementation and also evaluation/monitoring. Tourism Packages of PNT fishermen offered are (1) coastal exploration, exploring among fisherman's houses (Trekking Kampong), horse riding, hunting or biking along the beach; (2) interactive program with fisherman; (3) interactive program with family of fisherman in processing of traditional culinary (Culinary Education); (4) program culinary tour of "lauak karang / pukek"; (5) social service program; (6) stay at home of fisherman (Homestay Program); (7) learning program "siskamling anak nagari" and "makan bajamba" at night with art attraction traditional of "silek pasisie," "rabab pasisie" and "sepak rago" (Thematic Kampong Night); (8) Cultural program of local wisdom "tolak bala."

Some recommendations are as follows. (a) City government of Padang together with the Department of Tourism and Bappeda need to make the Master Plan, RDTR and 
Table 5

SWOT Matrix of PNT Fisherman Tourism Village Development

\begin{tabular}{|c|c|c|}
\hline Internal & $\begin{array}{l}\text { Strength (S) } \\
\text { 1. The attraction of PNT fishermen's } \\
\text { village that is still original/original } \\
\text { 2. High participation from PNT } \\
\text { community } \\
\text { 3. There are organizations or groups } \\
\text { society as as the embryo of the } \\
\text { birth of the tourism conscious } \\
\text { group as a tourist manager of PNT } \\
\text { fishing village } \\
\text { 4. Openness of communities towards } \\
\text { visitors / or tourist is quite high }\end{array}$ & $\begin{array}{l}\text { Weakness (W) } \\
\text { 1. Community participation in the } \\
\text { current fishermen tends to be } \\
\text { an object and not the subject } \\
\text { 2. Low education background } \\
\text { of fisherman community will } \\
\text { cause unoptimal management } \\
\text { of tourism lack of promotional } \\
\text { efforts fishing village } \\
\text { Limited funds for the } \\
\text { management or development } \\
\text { of tourist village }\end{array}$ \\
\hline $\begin{array}{l}\text { Opportunity }(\mathrm{O}) \\
\text { 1. There should be } \\
\text { support in the form } \\
\text { of regulation from } \\
\text { Padang government } \\
\text { that encourages the } \\
\text { development of the } \\
\text { fishing village of PNT } \\
\text { 2. CSR must participate } \\
\text { to w a } \mathrm{d} \text { s t h e } \\
\text { development of PNT } \\
\text { fishing village } \\
\text { 3. Fisherman's village } \\
\text { has a market that } \\
\text { is still widely open, } \\
\text { especially for foreign } \\
\text { tourists. } \\
\text { 4. Cooperation with } \\
\text { various stakeholders; } \\
\text { hotels, t } r \text { a } v \text { e I } \\
\text { agencies, print and } \\
\text { electronic media for } \\
\text { the promotion of new } \\
\text { destinations fishing } \\
\text { village of PNT }\end{array}$ & $\begin{array}{l}\text { Strategy of SO } \\
\text { 1. Involving the community in the } \\
\text { development of fisherman's } \\
\text { village tour of Pasie Nan Tigo } \\
\text { starting from the planning stage, } \\
\text { implementation and evaluation } \\
\text { (S1+S2+S3+S4+O1+O2+O3) } \\
\text { 2. Developing a typical fishing village } \\
\text { fishing village (based on local } \\
\text { wisdom) according to the potential } \\
\text { of the fisherman community of } \\
\text { PNT (S1+S4+O1+O2+O3) } \\
\text { 3. Establish Pokdarwis (Tourism } \\
\text { Awareness Group) Anak Nagari for } \\
\text { community-based tourist village } \\
\text { management with local wisdom. } \\
\text { (S2+S3+S4+O1) } \\
\text { 4. Promotion of PNT fishing village } \\
\text { community based through print } \\
\text { media, electronic and promotion } \\
\text { to hotel and travel agency. } \\
\text { (S1+S2+O2+O3+O4) }\end{array}$ & $\begin{array}{l}\text { Strategy of WO } \\
\text { 1. Mentoring the PNT community } \\
\text { to oversee the process of } \\
\text { development and management } \\
\text { of community-based tourist } \\
\text { villages and local wisdom } \\
\text { (W1+W2+W3+W4+O1) } \\
\text { 2. Increasing human resource } \\
\text { capacity of PNT communities by } \\
\text { conducting training, especially in } \\
\text { the field of tourism/tourist village } \\
\text { (W1+W2+W3+W4+O2+O3) } \\
\text { 3. Promotion of new tourism } \\
\text { destination of fishing village } \\
\text { Pasie Nan Tigo by involving } \\
\text { stakeholders. (W3+W4) }\end{array}$ \\
\hline $\begin{array}{l}\text { Threat (T) } \\
\text { 1. Lack of coordination } \\
\text { between SKPD and } \\
\text { related agencies } \\
\text { ( } D \text { e partment of } \\
\text { Tourism and Culture, } \\
\text { Fisheries and Maritime } \\
\text { Office, Bappeda, BPBD, } \\
\text { Social Agency, Office of } \\
\text { Kimpraswil-PU) } \\
\text { 2. C o r i n a t i o n } \\
\text { between Padang city } \\
\text { government and PNT } \\
\text { administrative village } \\
\text { with the fisherman } \\
\text { community of PNT is } \\
\text { still low. }\end{array}$ & \begin{tabular}{|l} 
Strategy of ST \\
Establish coordination between \\
Padang city government and \\
Pokdarwis Anak Nagari with the \\
improvement of urban village \\
$($ KSM $)$ capacity of Pasie Nan Tigo. \\
$(\mathrm{S} 2+\mathrm{S} 3+\mathrm{T} 1+\mathrm{T} 2)$
\end{tabular} & $\begin{array}{l}\text { Strategy of WT } \\
\text { Providing counseling, guidance } \\
\text { and socialization to the fisherman } \\
\text { community of PNT and the } \\
\text { general public of PNT about } \\
\text { the importance of developing } \\
\text { fishing village, the benefit for } \\
\text { the fishermen community as } \\
\text { an alternative livelihood, and } \\
\text { improving the welfare of the } \\
\text { fishermen community, especially } \\
\text { the community of PNT and } \\
\text { Padang city government. } \\
\text { (W1+W2+W3+W4+T } 1+T 2 \text { ) }\end{array}$ \\
\hline
\end{tabular}


DED development of local fisherman's fishing village based on local wisdom, b) The development of fishing village PNT is included as one of the new tourist destination programs in Padang City in RIPDA (Master Plan Tourism Development), c) The need for Padang City Regulation on the Establishment and Management of Fisherman's Village Tourism Village, d) Community-based Fisherman Tourism Village Development needs to be supported by a party especially city government of Padang through Tourism and Culture Office professionally and earnestly e) The need for guidance on human resources, especially fishermen community by relevant agencies to be ready to accept the development of fishing village as a tourist village, $f$ ) the formation of a group of Sadar Wisata "Anak Nagari" Kampung Nelayan Pasie Nan Tigo" as a governing institution for the sustainability of fishing village village; g) Promotion of new tourist destinations in Padang city, tourism of PNT fisherman village held in various mass media continuously, h) Cooperation between PNT and university of higher education continues to provide input for the sustainability of community-based tourism village development.

\section{References}

Buku Pedoman Kelompok Sadar Wisata oleh Kementerian Pariwisata dan Ekonomi Kreatif. (2012). Direktur Jenderal Pengembangan Destinasi Pariwisata Kementerian Pariwisata dan Ekonomi Kreatif . Januari. Jakarta.

Chafid Fandeli, Made Heny Urmila Dewi, M. Baiquni (2013). Pengembangan Desa Wisata Berbasis Partisipasi Masyarakat Lokal di Desa Wisata Jatiluwih Tabanan, Bali, Jurnal Kawistara, Vol. 3, No. 2, Agustus, Hal. 117-226.

Chafid Fandeli, Raharjana,D.T. Kaharudin (2013). Pengembangan Kawasan Pedesaan sebagai Objek Wisata (Perencanaan Model Kelembagaan, Pasar dan Paket Wisata Pedesaan Sekitar Gunung Merapi) Yogyakarata, Lembaga Penelitian Universitas Gadjah Mada.

Faris Zakaria dan Rima Dewi Suprihardjo (2014). Konsep Pengembangan Kawasan Desa Wisata di Desa Bandungan Kecamatan Pakong Kabupaten Pamekasan, Jurnal Teknik Pomits, Vol. 3, No.2.

Haryani Haryani, Lusi Utama (2016).
Revitalization Of Coastal Area Pasie Nan Tigo Padang City For Hazard Mitigation, Jurnal Mimbar, Vol.32, No.1, Juni, hal. 49-57.

Haryani, Huda, Nurul (2016). Feasibility Study of Coastal Tourism and Fishing Villages Development by Community Empowerment in Order to Support Fishermen's Alternative Livelihood, Internasional Journal on Advanced Science, Engineering and Information Technology.

Haryani (2014). Potensi Pengembangan Atraksi Wisata Kampung Nelayan Pasie Nan Tigo Padang di Tengah Ancaman Bencana Abrasi, Jurnal Mimbar, Vol.31, No.2, Desember, hal. 189-198.

Haryani (2012). Model Mitigasi Bencana di Wilayah Pesisir dengan Pemberdayaan Masyarakat, Jurnal Tataloka, Vol.14, No.3, Agustus, hal. 201-212, Biro Penerbit Planologi Undip.

Haryani dan Nurul Huda.( 2016). Potensi Pengembangan Wisata Kampung Nelayan denganPartisipasi Masyarakat sebagai Destinasi Wisata Baru: National Conference of Applied Sciences, Engineering, Business and Information Technology, Politeknik Negeri Padang, 15 - 16 Oktober 2016.

Haryani. (2014). Potensi Pengembangan Atraksi Wisata Kampung Nelayan Pasie Nan Tigo Kota Padang Ditengah Ancaman Bencana Abrasi Dan Banjir. Vol.30. No.2: 189-198.

Muhammad Syafii, Djoko Suwandono (2015). Perencanaan desa Wisata dengan Pendekatan Konsep Community Based Tourism (CBT) di Desa Bedono Kecamatan Sayung Kabupaten Demak, Jurnal Ruang, Vol.1 No.2, hal. 51-60.

PP No. 69 Tahun 1996 tentang Peran Serta Masyarakat

RIP Pariwisata Kota Padang 2008-2017

UU No.27 tahun 2007 tentang Pengelolaan Wilayah Pesisir dan Pulau-pulau Kecil

Undang-undang No. 26 Tahun 2007 tentang Penataan Ruang

Undang-undang No. 10 tahun 20009 tentang Kepariwisataan

Wearing, S.L., and Donald, Mc. (2001). The Development of Community Based Tourism: Re-Thinking The Relationship between Tour Operators and Development Agents as intermediaries in rural and isolated area Communities. Journal of Sustainable Tourism.

Yoeti, A Oka. 2008. Perencanaan dan Pengembangan Pariwisata 